\title{
RELAÇÃO DINÂMICA ENTRE RETORNO, VOLUME DE NEGOCIAÇÕES E VOLATILIDADE DAS AÇÕES DAS EMPRESAS DE CAPITAL ABERTO DO AGRONEGÓCIO BRASILEIRO
}

\author{
Valéria Gama Fully Bressan \\ Doutora em Economia Aplicada \\ Bolsista de Desenvolvimento Tecnológico Industrial do CNPq. \\ Departamento de Economia Rural \\ Universidade Federal de Viçosa \\ valeria.fully@gmail.com
}

Aureliano Angel Bressam

Doutor em Economia Aplicada Professor Adjunto da Faculdade de Ciências Econômicas Universidade Federal de Minas Gerais

Pesquisador do CNPq.

João Eustáquio de Lima

$\mathrm{PhD}$ pela University of Florida Professor Titular do Departamento de Economia Rural Universidade Federal de Viçosa Pesquisador do CNPq.

Marcelo José Braga

PhD pela University of Califórnia at Davis Professor Adjunto do Departamento de Economia Rural Universidade Federal de Viçosa

Pesquisador do CNPq.

\begin{abstract}
In order to verify similarities and/or differences on the behavior of returns and volatility on traded stocks of Brazilian agribusiness companies, this study examines the existence of leverage effects and tests the hypothesis that trading volume is a useful proxy for information innovations, for a sample of 25 stock-listed Brazilian agribusiness companies. Using daily data from July/1999 to January/2007, two specifications of EGARCH models are tested, with and without trading volume as an explanatory variable. The results confirm the existence of leverage effects for almost all of the analyzed companies, and some influence of trading volume in the explanation of the volatility dynamics, but without any remarkable differences between companies and/or their related sub-sectors.
\end{abstract}

Keywords: Financial Returns, Trading Volume, Volatility, EGARCH, Agribusiness. 
THE DYNAMIC RELATION BETWEEN

RETURNS, TRADING VOLUME AND

VOLATILITY IN BRAZILIAN STOCK-LISTED

AGRIBUSINESS COMPANIES
Valéria Gama Fully Bressan

Aureliano Angel Bressam

João Eustáquio de Lima

Marcelo José Braga

\section{INTRODUCTION}

The purpose of this paper is to examine the dynamic relation between stock returns, trading volume and volatility for 25 stock-listed Brazilian agribusinessrelated companies. Previous studies, such as those conducted by Chen, Firth and Rui (2001) and Tabak and Guerra (2003), evaluated such relation in stock markets of several countries, such as the United States, Japan, U. Kingdom, France, Canada, Italy, Hong Kong and Brazil. In an alternative approach, this study intends to evaluate this relation for a specific economic sector, in order to identify some specific features that could be observed in Brazilian agribusiness companies.

Specifically, the purpose of this paper is to evaluate if returns are conditioned by the arrival of new information that affect trading volume. The 25 companies in the analyzed sample are characterized as those which have stocks traded in the Brazilian Stock Exchange (BOVESPA) until January 2007. These companies represent specific activities, such as fishery and agriculture, foods and beverages, paper and pulp, textiles, fertilizers, tobacco and industrial machinery, classified according to Economática's database.

The analysis is based on an EGARCH model that is estimated in order to verify the existing relations between returns, trading volume and conditional volatility. The results are analyzed in a comparative manner, intending to verify possible similarities and differences between sectors and companies.

RC\&C - Rev. Cont. e Controladoria ISSN: 1984-6266
The investigation about the relation between stock returns and trading volume is an important issue in financial research. Karpoff (1987) lists three main reasons for the importance of researches regarding this relation. First, the returns/trading volume relation provides important insights about the structure of financial markets. Second, its importance for event studies that use these relations to draw inferences about market efficiency. Third, that relation is a critical issue in the investigation of the empirical distribution of speculative prices.

The returns/trading volume relation is studied with different approaches among researchers. For instance, Granger and Morgenstern (1963) used the relation between stock indexes and aggregated transaction volume, while Crouch (1970) worked with the absolute variation of prices and trading volume. Westerfield (1977), Tauchen and Pitts (1983) and Rogalski (1978) analyzed the relation between price variations (returns) and trading volume. Epss and Epps (1976) examined the relation between the variance of returns and trading volume, while Harris (1986) and Clark (1973) investigated the relation between the square of price variations and trading volume.

Some recent results in the literature are of special interest to this study. Gallant, Rossi and Tauchen (1992), using daily data from the New York Stock Exchange between 1928 and 1987, investigated the returns/trading volume relation, with some interesting results: (i) positive correlation between conditional volatility and trading volume, (ii) large price movements are followed by high trading volume, (iii) the conditioning on trading volume reduces the leverage effect on volatility, and (iv) after conditioning on

$\begin{array}{lllll}\text { Curitiba } & \text { v. } 1 & \text { n. } 2 & \text { p. } 89-101 & \text { mai./ago. } 2009\end{array}$ 
THE ACCOUNTANCY OF THE POTENTIAL INCOME LOST DUE PREMATURE DEATH: DIFFERENCES DETERMINED BY GENDER
Valéria Gama Fully Bressan

Aureliano Angel Bressam

João Eustáquio de Lima

Marcelo José Braga lagged volume, there is a positive relation between risk and return.

Andersen (1996) developed an empirical model of trading volume and volatility from a microstructure framework in which informational asymmetries and lack of liquidity motivates the negotiation derived from the arrival of new information. Using a sequential information arrival hypothesis, the dynamic characteristics are driven by the information flow and modeled as an $\mathrm{ARCH}$ process. The results indicate that the model can be useful for the analysis of economic factors that are behind the observed volatility clusters.

Chordia and Swaminathan (2000) examined the interaction between trading volume and return predictability of daily returns. The results indicated that returns with high trading volume lead stock returns with low trading volume, a result that was explained by the authors as a tendency of high volume stocks to respond promptly to new information. Kuo, Hsu and Chiang (2004) applied the same model of Chordia and Swaminathan (2000) for the Taiwanese market, finding similar results along with some market inefficiencies.

Although these studies have some implications for causal relations between trading volume and stock returns, neither has analyzed a specific economic sector, in order to confirm or reject the results found in the literature. In this study, such empirical relations are examined for 25 stock-listed Brazilian agribusiness companies, in order to identify the existing relations between returns and trading volume.

\section{THE DATA}

This paper analyzes all the companies listed in BOVESPA wich are classified in one of three sub-sectors of Brazilian agribusiness, namely: agricultural production, economic inputs and production factors and processing \& distribution sector.

The daily price and trading volume data of these stocks were extracted from Economatica ${ }^{\circledR}$ database from July/1994 to January/2007. Initially the sample was composed by 35 companies. However, those which have their register cancelled during that period were excluded from the sample, resulting in a final sample of 25 companies: Alpargatas, Ambev, Aracruz, Avipal, Buettner, Cacique, Cambuci, Coteminas, Fertibras, Fosfertil, Guararapes, Klabin, Minupar, Perdigão, Rasip Agro Pastoril, Sadia, Santista Têxtil, Souza Cruz, Suzano Papel, Teka, Vicunha Têxtil, Vigor, Votorantim C P, Weg and Yara Brasil.

The returns were calculated in the logarithmic form, resulting $\mathrm{Rt}=\log \left(\mathrm{Pt} / \mathrm{P}_{\mathrm{t}-1}\right)$, where $P t$ is current price and $P_{t-1}$ is the 1-period lagged price. The volume is the product between the current price and the number of traded stocks on the specific class (common or preferred stocks). Volatility is defined as the square-root of the square of returns, according to the zero-mean hypothesis of expected returns, as described in Taylor (2005).

\section{THE MODEL}

Following Enders (2004), an important feature of stock prices is that "bad" news tends to have a higher effect on volatility 
THE ACCOUNTANCY OF THE POTENTIAL INCOME LOST DUE PREMATURE DEATH: DIFFERENCES DETERMINED BY GENDER
Valéria Gama Fully Bressan

Aureliano Angel Bressam

João Eustáquio de Lima

Marcelo José Braga

then "good" news of the same magnitude, a stylized fact known in the literature as "leverage effect".

Another special feature is that financial returns tend to exhibit fat tails in their distributions and for that reason GARCHbased models are widely applied in financial literature, once that these models can incorporate not only the leptokurtosis of squared returns, but also their lagged dependence. Among the existing models in the GARCH family, this study uses the EGARCH (Exponential Generalized Autoregressive Conditional Heteroscedasticity) following the previous applications of Hiemstra and Jones (1994), Silvapulle and Choi (1999) and Chen, Firth and Rui (2001).

The adequacy of the EGARCH model was exposed by Nelson (1991) which shown that it is better suited for daily

Mean Equation:

$$
\begin{gathered}
R_{t}=a+b R_{t-1}+\varepsilon_{t} \\
\varepsilon \mid I_{t-1} \sim N\left(0, h_{t}\right) .
\end{gathered}
$$

Variance Equation:

$$
\ln \left(h_{t}\right)=\alpha_{0}+\alpha_{1}\left(\frac{\varepsilon_{t-1}}{h_{t-1}{ }^{0,5}}\right)+\lambda_{1}\left|\frac{\varepsilon_{t-1}}{h_{t-1}{ }^{0,5}}\right|+\beta_{1} \ln \left(h_{t-1}\right)
$$

Equation (2) defines the EGARCH model, which presents the following interesting features: (i) the equation for the conditional variance is in log-linear form and, as a consequence, the ht term that represents conditional variance can not be negative; (ii) instead of using $\varepsilon_{t-1}^{2}$, the EGARCH model uses the level of the standarized residual data with persistence in volatility, presenting conditional lognormal variance in continuous time. As a consequence, as the time interval becomes shorter, the innovations distribution is a mixture of normal and lognormal distributions. In this sense, Hiemstra and Jones (1994) argue that the EGARCH model is better suited to verify causal relations between trading volume and stock returns. However, Alexander (2001) mentions that forecasting from EGARCH models is a difficult task, since an analytical form for the volatility term cannot be defined precisely.

Following Chen, Firth and Rui (2001), the present study uses an EGARCH $(1,1)$ specification, which defines a model for the estimation of the dynamics of returns volatility as: $\varepsilon_{\mathrm{t}-1}\left(\right.$ i.e., $\left.\varepsilon_{\mathrm{t}-1} /\left(\mathrm{h}_{\mathrm{t}-1}\right)^{0,5}\right)$, allowing an easier interpretation of the size and persisitence of shocks, with the standardized value as a unit measure (ENDERS, 2004); (iii) the EGARCH model captures the leverage effect when $\alpha_{1}$ is statistically different from zero (Morettin and Toloi, 2004) and, according to Brooks (2002), if the relation between volatility and return is 
negative, then $\alpha_{1}$ must be negative, indicating then the leverage effect.

The $\beta_{1}$ coefficient in the variance equation tends to be, according to Chen, Firth and Rui (2001) considerably higher than $\alpha_{1}$, indicating that unexpected market movements induce to relatively small adjustments in the expected volatility. The persistence in the conditional variance process, which is measured by $\alpha_{1}+\beta_{1}$, is high and in most cases close to unity, with higher values associated with a greater persistence in volatility.

In order to examine the hypothesis that the information flow to the market helps to explain the volatility of returns, a lagged volume term - denoted by $V_{t-1}$ - is included in the variance equation as a proxy to information innovations, following Chen, Firth and Rui (2001). In this sense, the daily trading volume was used as a measure of the quantity of daily information that arrives to the market. This model is defined by the following equations:

Mean Equation:

$$
\begin{aligned}
& R_{t}=a+b R_{t-1}+\varepsilon_{t} \\
& \varepsilon \mid I_{t-1} \sim N\left(0, h_{t}\right) .
\end{aligned}
$$

Variance Equation:

$$
\ln \left(h_{t}\right)=\alpha_{0}+\alpha_{1}\left(\frac{\varepsilon_{t-1}}{h_{t-1}{ }^{0,5}}\right)+\lambda_{1}\left|\frac{\varepsilon_{t-1}}{h_{t-1}{ }^{0,5}}\right|+\beta_{1} \ln \left(h_{t-1}\right)+\chi_{1} V_{t-1}
$$

The expected sign of the coefficient of the lagged volume, according to Chen, Firth and Rui (2001) is positive and, in the presence of volume with $\chi_{1}>0, \alpha_{1}$ and $\beta_{1}$ tend to be statistically insignificant. Also, the persistence in variance measured by $\alpha_{1}+\beta_{1}$ tends do become negligible if accounting for the uneven flow of information $(V)$ explains the presence of EGARCH in the data.

Finally, according to Najand and Yung (1991) and Watanabe (2001), inferences in equation (4) can be made only if volume is exogenous and therefore lagged volume $\left(V_{t-1}\right)$ is included in the model specification.

\section{EMPIRICAL RESULTS}

In consonance with Chen, Firth and Rui (2001) the analyzed series presents timevariant volatility, a well-known fact in financial returns. As shown in Tables 1a to 1c, the Maximum Likelihood (ML) statistics are high for 18 of the 25 analyzed stocks. This result indicates that the EGARCH is an adequate model to describe the time dependence in daily returns. It is important to notice that the stocks with lower liquidity - Buettner, Cacique, Cambuci, Perdigão, Rasip, Vicunha and Vigor - don't show significant ML statistics. These stocks,

$\begin{array}{llllll}\text { Curitiba } & \text { v. } 1 & \text { n. } 2 & \text { p. } 89-101 & \text { mai./ago. } 2009\end{array}$ 
and also the stocks from Avipal and Sadia, were excluded of the analysis due to the absence of statistically significant $\mathrm{ARCH}$ effects.

Among the companies whose stocks presented ARCH effects - Alpargatas, Ambev, Aracruz, Coteminas, Fosfertil, Guararapes, Klabin, Minupar, Santinsta, Souza Cruz, Teka, Votorantim, Weg and Yara Brasil - the majority of the EGARCH estimates for Equation (2) were statistically significant, with an exception made for the results of Minupar and Suzano. The $\beta$ coefficient was considerably higher then $\alpha$, indicating that unexpected market movements induce to relatively small changes in expected volatility. The persistence in volatility, measured by $\alpha+\beta$, was close to unity, except for the results of Santista's stocks. The obtained results also indicate that current information is relevant to predict future volatility in the short run.

TABLE 1-A-ESTIMATION RESULTS FOR THE EGARCH MODELS OF BRAZILIAN AGRIBUSINESS COMPANIES

\begin{tabular}{|c|c|c|c|c|c|c|c|c|}
\hline Company & Alpargatas & Ambev & Aracruz & Avipal & Buettner & Cacique & Cambuci & Coteminas \\
\hline \multirow[t]{2}{*}{$a$} & 0,003 & 0,0009 & 0,0008 & 0,00069 & 0,005 & 0,007 & $-0,007$ & 0,0004 \\
\hline & $(6,976)^{*}$ & $(2,427)^{* *}$ & $(2,129)^{* *}$ & $(1,297) n s$ & $(0,657) n s$ & $(3,973) *$ & $(-3,432) *$ & $(0,987) \mathrm{ns}$ \\
\hline \multirow[t]{2}{*}{$b$} & $-0,055$ & 0,066 & 0,008 & $-0,131$ & $-0,038$ & $-0,159$ & 0,042 & 0,0358 \\
\hline & $(-2,919) *$ & $(3,600)^{*}$ & $(0,509) \mathrm{ns}$ & $(-5,791) *$ & $(-0,57) n s$ & $(-3,525) *$ & $(1,051) n s$ & $(1,945)^{* * *}$ \\
\hline \multirow{2}{*}{$\alpha_{0}$} & $-0,197$ & $-0,858$ & $-0,098$ & $-1,605027$ & $-5,078$ & $-0,779$ & 0,005 & $-0,537$ \\
\hline & $(-13,977)^{*}$ & $(-15,951)^{*}$ & $(-14,199)^{*}$ & $(-13,86) *$ & $(-4,734) *$ & $(-4,813) *$ & $(0,469) n s$ & $(-13,993)^{*}$ \\
\hline \multirow{2}{*}{$\lambda_{1}$} & 0,145 & 0,304 & 0,124 & 0,3707 & 0,008 & 0,252 & $-0,025$ & 0,227 \\
\hline & $(22,551)^{*}$ & $(21,948)^{*}$ & $(19,147)^{*}$ & $(18,588) *$ & $(0,112) n s$ & $(5,419) *$ & $(-2,353) * *$ & $(18,969)^{*}$ \\
\hline \multirow{2}{*}{$\alpha_{1}$} & $-0,025$ & $-0,069$ & $-0,039$ & $-0,0376$ & 0,207 & 0,045 & $-0,087$ & $-0,048$ \\
\hline & $(-3,918) *$ & $(-7,309)^{*}$ & $(-8,681)^{*}$ & $(-2,596) *$ & $(3,519) *$ & $(1,763) * * *$ & $(-12,698)^{*}$ & $(-6,279) *$ \\
\hline \multirow{2}{*}{$\beta_{1}$} & 0,986 & 0,917 & 0,999 & 0,8001 & $-0,187$ & 0,892 & 0,995 & 0,949 \\
\hline & $(537,484)^{*}$ & $(151,799)^{*}$ & $(1289,937)^{*}$ & $(50,452) *$ & $(-0,74) n s$ & $(36,544)^{*}$ & $(653,245) *$ & $(204,691)^{*}$ \\
\hline L-Box (24) & 17,072 & 29,691 & 35,663 & 30,500 & 57,900 & 21,221 & 33,489 & 30,515 \\
\hline For the mean & {$[0,806]$} & {$[0,158]$} & {$[0,045)$} & {$[0,136]$} & {$[0,000]$} & {$[0,568]$} & {$[0,073]$} & {$[0,135]$} \\
\hline L-Box (24) & 58,478 & 16,863 & 65,568 & 23,349 & 18,130 & 14,497 & 30,586 & 20,316 \\
\hline For the variance & {$[0,000]$} & {$[0,816]$} & {$[0,000]$} & {$[0,441]$} & {$[0,750]$} & {$[0,912]$} & {$[0,133]$} & {$[0,623]$} \\
\hline ML & 5044,939 & 7558,767 & 7029,881 & 4790,669 & 262,1736 & 1016,369 & 435,2508 & 6273,373 \\
\hline LM Test & $7,256^{*}$ & $3,149 * * *$ & $40,369 *$ & $2,128 n s$ & $0,003 n s$ & $0,928 n s$ & $0,794 n s$ & $7,843 *$ \\
\hline$\alpha_{1}+\beta_{1}$ & 0,961 & 0,848 & 0,96 & 0,763 & 0,02 & 0,937 & 0,908 & 0,901 \\
\hline $\begin{array}{c}\mathrm{ns}=\text { non-signific } \\
\text { p-value. }\end{array}$ & ML $=$ Maxin & n Likelihoo & * $10 \%$ rianifis & e; $* * 5 \%$ & nificance; & $* 10 \%$ signi & & tatistic; [ ] \\
\hline
\end{tabular}

The leverage effect was verified in the returns of Alpargatas, Ambev, Aracruz, Coteminas, Fosfertil, Guararapes, Klabin, Souza Cruz, Teka, Votorantim, Weg and
Yara Brasil stocks, indicating that negative shocks generate higher volatility in the returns than positive shocks of same magnitude. 
TABLE 1-B - ESTIMATION RESULTS FOR THE EGARCH MODELS OF BRAZILIAN AGRIBUSINESS COMPANIES

\begin{tabular}{|c|c|c|c|c|c|c|c|c|}
\hline Company & Fosfertil & Fertibras & Guararapes & Klabin & Minupar & Perdigão & Rasip & Sadia \\
\hline \multirow[t]{2}{*}{$a$} & 0,001 & 0,002 & 0,003 & 0,0012 & $-0,006$ & 0,004 & 0,0038 & 0,0007 \\
\hline & $(3,839)^{*}$ & $(3,239) *$ & $(4,954)^{*}$ & $(2,812)^{*}$ & $(-5,587)^{*}$ & $(2,717) *$ & $(2,319) * *$ & $(1,561) n s$ \\
\hline \multirow[t]{2}{*}{$b$} & $-0,011$ & $-0,114$ & $-0,219$ & $-0,003$ & $-0,255$ & $-0,059$ & $-0,352$ & 0,0619 \\
\hline & $(-0,627) \mathrm{ns}$ & $(-4,821) *$ & $(-9,269) *$ & $(-0,184) \mathrm{ns}$ & $(-12,093)^{*}$ & $(-1,371) n s$ & $(-10,38) *$ & $(3,349) *$ \\
\hline \multirow{2}{*}{$\alpha_{0}$} & $-0,187$ & $-0,232$ & $-0,389$ & $-0,583$ & $-0,239$ & $-0,139$ & $-0,679$ & $-0,466$ \\
\hline & $(-12,495)^{*}$ & $(-15,286) *$ & $(-14,091)^{*}$ & $(-11,568)^{*}$ & $(-11,646)^{*}$ & $(-8,798) *$ & $(-9,063) *$ & $(-9,651) *$ \\
\hline \multirow{2}{*}{$\lambda_{1}$} & 0,151 & 0,230 & 0,241 & 0,245 & 0,197 & $-0,021$ & 0,203 & 0,183 \\
\hline & $(19,577)^{*}$ & $(22,869) *$ & $(23,587)^{*}$ & $(19,624)^{*}$ & $(15,527)^{*}$ & $(-1,147) n s$ & $(9,377)^{*}$ & $(11,444) *$ \\
\hline \multirow{2}{*}{$\alpha_{1}$} & $-0,016$ & $-0,032$ & $-0,018$ & $-0,045$ & $-0,0072$ & 0,129 & 0,071 & $-0,048$ \\
\hline & $(-3,549) *$ & $(-4,332) *$ & $(-2,729) *$ & $(-4,708)^{*}$ & $(-0,695) \mathrm{ns}$ & $(9,735) *$ & $(3,098) *$ & $(-5,559) *$ \\
\hline \multirow{2}{*}{$\beta_{1}$} & 0,989 & 0,989 & 0,964 & 0,943 & 0,982 & 0,977 & 0,894 & 0,9554 \\
\hline & $(586,138)^{*}$ & $(456,319) *$ & $(254,686)^{*}$ & $(149,081)^{*}$ & $(295,738)^{*}$ & $(353,231) *$ & $(71,478) *$ & $(175,976) *$ \\
\hline L-Box (24) & 32,051 & 37,795 & 36,600 & 20,336 & 22,811 & 16,787 & 36,235 & 44,429 \\
\hline $\begin{array}{l}\text { For the } \\
\text { mean }\end{array}$ & {$[0,099]$} & {$[0,027]$} & {$[0,036]$} & {$[0,622]$} & {$[0,472]$} & {$[0,820]$} & {$[0,039]$} & {$[0,005]$} \\
\hline L-Box (24) & 44,366 & 21,117 & 34,937 & 21,294 & 26,485 & 22,151 & 20,484 & 16,222 \\
\hline $\begin{array}{l}\text { For the } \\
\text { variance }\end{array}$ & {$[0,005]$} & {$[0,574]$} & {$[0,053]$} & {$[0,563]$} & {$[0,279]$} & {$[0,511]$} & {$[0,613]$} & {$[0,846]$} \\
\hline $\mathrm{ML}$ & 7277,771 & 3897,274 & 3447,705 & 6550,307 & 2730,757 & 617,0271 & 1078,986 & 7162,892 \\
\hline LM Test & $20,411^{*}$ & $0,078 n s$ & $3,922 * *$ & $7,632 *$ & $16,128^{*}$ & $0,368 n s$ & $0,189 n s$ & $2,333 n s$ \\
\hline$\alpha_{1}+\beta_{1}$ & 0,973 & 0,957 & 0,946 & 0,898 & 0,975 & 1,106 & 0,965 & 0,907 \\
\hline $\begin{array}{r}\mathrm{ns}=\text { non-sig } \\
\text { value. }\end{array}$ & ant; $\mathrm{ML}=$ & imum Lik & $\mathrm{d} ; * 1 \%$ sigr & $\mathrm{ice} ; * * 5$ & ificicance; * & $\%$ signific & ( ) z stat & ; [ ] p- \\
\hline
\end{tabular}

The results for Minupar and Suzano $\alpha_{1}$ coefficients were statistically nonsignificant, indicating the absence of leverage effect for these companies, with that same coefficient presenting a positive result for the Santista's data.

In order to verify the estimated models, the Ljung-Box Q statistic was calculated for the standardized residuals and also to the square of those residuals, considering 24 lags. The obtained results indicate that the models estimated for Ambev, Coteminas, Fosfertil, Klabin, Minupar, Souza Cruz and Yara Brasil do not show any statistically significant serial correlation in the residuals (Tables 1-a to 1-c). Alternatively, the residuals of Aracruz, Alpargatas, Guararapes,
Santista, Suzano, Teka, Votorantim and Weg presented serial correlation but, considering that the estimated models were not constructed to produce forecasts, that issue does not make invalid the analysis of the return/trading volume relation.

The verification of the hypothesis that the information flow in the market helps to explain the return volatility is tested by the estimation of equations (3) and (4), shown on Tables 2-a to 2-c. The estimated results for the $\alpha$ and $\beta$ coefficients were statistically significant for almost all equations, exception made for the $\alpha$ coefficient of the models constructed for Minupar and Vigor returns. 
Table 1-c - Estimation Results for the EGARCH models of Brazilian agribusiness companies

\begin{tabular}{|c|c|c|c|c|c|c|c|c|c|}
\hline Company & Santista & Souza Cruz & Suzano & Teka & Vicunha & Vigor & Votorantim & Weg & Yara Brasil \\
\hline \multirow[t]{2}{*}{$a$} & 0,002 & 0,001 & 0,0014 & $-0,002$ & $-0,003$ & 0,004 & 0,0006 & 0,002 & $-0,001$ \\
\hline & $(4,24)^{*}$ & $(2,615)^{*}$ & $(2,977)^{*}$ & $(-2,4)^{* *}$ & $(-2,453) * *$ & $(2,73) *$ & $(1,287) \mathrm{ns}$ & $(4,84)^{*}$ & $(-1,246) \mathrm{ns}$ \\
\hline \multirow[t]{2}{*}{$b$} & $-0,076$ & $-0,013$ & $-0,0003$ & $-0,159$ & $-0,333$ & 0,047 & 0,0474 & $-0,072$ & $-0,139$ \\
\hline & $(-12,23)^{*}$ & $(-0,75) \mathrm{ns}$ & $(-0,02) \mathrm{ns}$ & $(-7,96)^{*}$ & $(-6,100) *$ & $(1,98)^{* * *}$ & $(2,934)^{*}$ & $(-3,92)^{*}$ & $(-7,567)^{*}$ \\
\hline \multirow{2}{*}{$\alpha_{0}$} & $-10,393$ & $-0,535$ & $-0,226$ & $-0,294$ & $-0,815$ & $-0,139$ & $-0,381$ & $-0,104$ & $-0,067$ \\
\hline & $(-380,9)^{*}$ & $(-10,73)^{*}$ & $(-10,29)^{*}$ & $(-9,09) *$ & $(-16,604) *$ & $(-11,80)^{*}$ & $(-12,198)^{*}$ & $(-9,69)^{*}$ & $(-12,765)^{*}$ \\
\hline \multirow{2}{*}{$\lambda_{1}$} & 0,415 & 0,218 & 0,147 & 0,191 & 0,682 & 0,151 & 0,193 & 0,101 & 0,096 \\
\hline & $(83,13)^{*}$ & $(15,43)^{*}$ & $(14,21)^{*}$ & $(15,16)^{*}$ & $(22,889) *$ & $(16,27)^{*}$ & $(17,471)^{*}$ & $(17,34)^{*}$ & $(17,143)^{*}$ \\
\hline \multirow{2}{*}{$\alpha_{1}$} & 0,229 & $-0,017$ & $-0,003$ & $-0,016$ & $-0,159$ & $-0,005$ & $-0,034$ & $-0,019$ & $-0,025$ \\
\hline & $(88,99)^{*}$ & $(-2,21)^{* *}$ & $(-0,57) \mathrm{ns}$ & $(-1,9) * *$ & $(-6,297) *$ & $(-0,71) n s$ & $(-4,782) *$ & $(-3,58)^{*}$ & $(-5,977)^{*}$ \\
\hline \multirow{2}{*}{$\beta_{1}$} & $-0,659$ & 0,949 & 0,983 & 0,974 & 0,929 & 0,993 & 0,967 & 0,995 & 0,999 \\
\hline & $(-134,5)^{*}$ & $(159,37)^{*}$ & $(391,91)^{*}$ & $(197,7)^{*}$ & $(103,932)^{*}$ & $(503,42) *$ & $(254,599)^{*}$ & $(769,91)^{*}$ & $(1619,882)^{*}$ \\
\hline L-Box (24) & 198,32 & 27,093 & 23,786 & 14,746 & 27,246 & 44,670 & 30,794 & 29,814 & 28,368 \\
\hline $\begin{array}{l}\text { For the } \\
\text { mean }\end{array}$ & {$[0,00]$} & {$[0,252]$} & {$[0,41]$} & {$[0,904]$} & {$[0,246]$} & {$[0,004]$} & {$[0,128]$} & {$[0,155]$} & {$[0,202]$} \\
\hline L-Box (24) & 143,35 & 33,050 & 41,834 & 48,030 & 22,788 & 17,695 & 100,33 & 57,022 & 23,730 \\
\hline $\begin{array}{l}\text { For the } \\
\text { variance }\end{array}$ & {$[0,00]$} & {$[0,080]$} & {$[0,009]$} & {$[0,00]$} & {$[0,473]$} & {$[0,774]$} & {$[0,000]$} & {$[0,00]$} & {$[0,419]$} \\
\hline ML & 2789,27 & 7168,47 & 6104,27 & 3756,12 & 712,1791 & 1747,071 & 6676,139 & 5295,16 & 2566,382 \\
\hline LM Test & $3,963 * *$ & $2,82 * * *$ & $10,32 *$ & $32,66 *$ & $0,218 n s$ & $1,609 n s$ & $65,414 *$ & $5,45 * *$ & $9,604 *$ \\
\hline$\alpha_{1}+\beta_{1}$ & $-0,432$ & 0,932 & 0,981 & 0,958 & 0,77 & 0,988 & 0,933 & 0,976 & 0,974 \\
\hline
\end{tabular}

The trading volume coefficient $\chi_{1}$ was significant for the majority of the estimated models, with exceptions related to the results of Aracruz, Fosfertil, Klabin, Suzano, Weg, Teka and Yara Brasil which were non significant, and for the results of Minupar, which presented a negative sign.

The EGARCH effect remains significant when the lagged volume is included in the model. Nevertheless, the persistence in volatility is marginally lower then the results of equations (1) and (2) presented in Table 1, for the majority of the analyzed companies. Volume as a proxy for information innovations does not reduce the importance of $\alpha$ and $\beta$ in the representation of the dynamics of volatility of the Brazilian agribusiness companies. These results are different from those expected in the specification of Chen, Firth and Rui (2001), generating a different interpretation of these estimates.

Such results suggest that volatility is better explained by its past behavior than by volume. The significance of coefficient $\chi_{1}$ can be an indication that volume is an endogenous variable and that, for most of the analyzed series there exists a positive relation between the variance of returns ant past trading volume. Another possible

$\begin{array}{lllll}\text { Curitiba } & \text { v. } 1 & \text { n. } 2 & \text { p. } 89-101 & \text { mai./ago. } 2009\end{array}$ 
interpretation of this result is that volume is an inadequate proxy for information innovation.

It is important to notice that these results corroborate the view of Blume, Easley and O'Hara (1994), which argue that trading volume informs about the quality of the signs generated by information innovations, instead of representing the information signal itself. The authors also argue that a possible reason for the fact that information does not explain volatility is associated with the existence of noise trading in the market, as proposed by Black (1986).

Table 2-a - Estimation results of the EGARCH model with lagged trading volume

\begin{tabular}{|c|c|c|c|c|c|c|c|c|}
\hline Company & Alpargatas & Ambev & Aracruz & Avipal & Buettner & Cacique & Cambuci & Coteminas \\
\hline \multirow[t]{2}{*}{$a$} & 0,003 & 0,0008 & 0,0007 & $-0,0008$ & 0,006 & 0,007 & $-0,009$ & 0,0004 \\
\hline & $(6,805)^{*}$ & $(2,433) * *$ & $(2,122)^{* * *}$ & $(-1,6) * * *$ & $(0,72) n s$ & $(3,44) *$ & $(-3,995) *$ & $(1,05) \mathrm{ns}$ \\
\hline \multirow[t]{2}{*}{$b$} & $-0,059$ & 0,064 & 0,008 & $-0,135$ & $-0,027$ & $-0,158$ & 0,073 & 0,032 \\
\hline & $(-3,150)^{*}$ & $(3,43) *$ & $(0,504) \mathrm{ns}$ & $(-5,699) *$ & $(-0,58) n s$ & $(-3,62) *$ & $(1,472) n s$ & $(1,7)^{* * *}$ \\
\hline \multirow{2}{*}{$\alpha_{0}$} & $-0,171$ & $-0,892$ & $-0,098$ & $-2,215$ & $-5,189$ & $-0,702$ & $-0,103$ & $-0,525$ \\
\hline & $(-13,468)^{*}$ & $(-15,15) *$ & $(-12,99)^{*}$ & $(-15,32)^{*}$ & $(-6,24) *$ & $(-4,77) *$ & $(-11,80) *$ & $(-13,9)^{*}$ \\
\hline \multirow{2}{*}{$\lambda_{1}$} & 0,133 & 0,310 & 0,124 & 0,419 & $-0,014$ & 0,205 & 0,079 & 0,224 \\
\hline & $(22,231)^{*}$ & $(21,22) *$ & $(17,89)^{*}$ & $(18,186) *$ & $(-0,24) n s$ & $(5,60) *$ & $(7,629) *$ & $(18,81)^{*}$ \\
\hline \multirow{2}{*}{$\alpha_{1}$} & $-0,035$ & $-0,069$ & $-0,039$ & $-0,066$ & 0,282 & 0,013 & $-0,165$ & $-0,047$ \\
\hline & $(-5,641)^{*}$ & $(-7,27) *$ & $(-8,635)^{*}$ & $(-3,775) *$ & $(4,807) *$ & $(0,48) n s$ & $(-13,70) *$ & $(-6,11)^{*}$ \\
\hline \multirow{2}{*}{$\beta_{1}$} & 0,989 & 0,913 & 0,999 & 0,715 & $-0,211$ & 0,901 & 0,985 & 0,950 \\
\hline & $(590,221)^{*}$ & $(137,35)^{*}$ & $(1264,9)^{*}$ & $(35,678) *$ & $(-1,09) n s$ & $(39,30) *$ & $(696,34) *$ & $(208,7)^{*}$ \\
\hline \multirow{2}{*}{$\chi_{1}$} & $1,58 \mathrm{E}-08$ & $1,04 E-09$ & $9,44 \mathrm{E}-12$ & $3,65 E-07$ & $3,52 E-06$ & $3,06 E-07$ & $1,74 E-09$ & 4,34E-09 \\
\hline & $(5,771)^{*}$ & $(2,60) *$ & $(0,013) \mathrm{ns}$ & $(7,520) *$ & $(2,88)$ & $(3,35) *$ & $(0,019) n s$ & $(2,595)^{*}$ \\
\hline L-Box (24) & 16,699 & 29,878 & 35,669 & 33,454 & 52,931 & 23,454 & 24,663 & 30,824 \\
\hline $\begin{array}{l}\text { For the } \\
\text { mean }\end{array}$ & {$[0,824]$} & {$[0,153]$} & {$[0,045]$} & {$[0,073]$} & {$[0,000]$} & {$[0,435]$} & {$[0,368]$} & {$[0,127]$} \\
\hline L-Box (24) & 59,989 & 17,246 & 65,520 & 29,608 & 16,260 & 16,386 & 17,553 & 18,415 \\
\hline $\begin{array}{l}\text { For the } \\
\text { variance }\end{array}$ & {$[0,000]$} & {$[0,797]$} & {$[0,000]$} & {$[0,161]$} & {$[0,844]$} & {$[0,83]$} & {$[0,781]$} & {$[0,735]$} \\
\hline ML & 5056,157 & 7560,10 & 7029,88 & 4802,52 & 265,278 & 1021,35 & 415,34 & 6274,23 \\
\hline LM Test & $7,177^{*}$ & $2,473 n s$ & $40,308^{*}$ & $0,439 n s$ & $0,010 \mathrm{~ns}$ & $0,439 n s$ & $0,02 n s$ & $6,957 *$ \\
\hline$\alpha_{1}+\beta_{1}$ & 0,954 & 0,844 & 0,96 & 0,649 & 0,071 & 0,914 & 0,82 & 0,903 \\
\hline
\end{tabular}

$\mathrm{ns}=$ non-significant; $\mathrm{ML}=$ Maximum Likelihood; $* 1 \%$ significance; $* * 5 \%$ significance; $* * * 10 \%$ significance; ( ) z statistic; [ ] p-value Note: The information in italic were excluded from the analysis as a result of the non-rejection of the null hypothesis in the LM test. Source: Estimation results. 


\section{CONCLUSIONS}

The analysis of the ARCH effects in the returns of the Brazilian agribusiness stocklisted companies indicate that the stocks of Buettner, Cacique, Cambuci, Perdigão, Rasip, Vicunha and Vigor did not present any significant ARCH effects, a result that is possibly related to the low liquidity of those stocks in the analyzed period. On the other hand, the stocks of Alpargatas, Ambev, Aracruz, Coteminas, Fosfertil, Guararapes, Klabin, Minupar, Santinsta, Souza Cruz, Teka, Votorantim, Weg and Yara Brasil presented only ARCH effects, with persistence in volatility and leverage effects.

The results do not have any sector-specific issues, with a common feature that all the companies with high liquidity presented some similar results: shocks in the conditional variance take a long time to die out in the majority of the analyzed stocks, while the persistence in volatility, measured by $\alpha+\beta$, was close to unity, indicating that current information is relevant to predict future volatility in the short run for the analyzed sample. This is an important issue for risk managers and investors that take into account these assets in their porfolios.

Table 2-b - Estimation results of the EGARCH model with lagged trading volume

\begin{tabular}{|c|c|c|c|c|c|c|c|c|}
\hline Company & Fosfertil & Fertibras & Guararapes & Klabin & Minupar & Perdigão & Rasip & Sadia \\
\hline \multirow[t]{2}{*}{$a$} & 0,001 & 0,002 & 0,003 & 0,001 & $-0,006$ & 0,0002 & 0,004 & 0,0007 \\
\hline & $(3,831)^{*}$ & $(3,298) *$ & $(4,539)^{*}$ & $(2,799)^{*}$ & $(-5,57)^{*}$ & $(0,21) n s$ & $(2,2) * *$ & $(1,6) * * *$ \\
\hline \multirow[t]{2}{*}{$b$} & $-0,010$ & $-0,111$ & $-0,223$ & $-0,004$ & $-0,253$ & $-0,089$ & $-0,332$ & 0,061 \\
\hline & $(-0,612) \mathrm{ns}$ & $(-4,692) *$ & $(-9,105)^{*}$ & $(-0,19) \mathrm{ns}$ & $(-12,12)^{*}$ & $(-2,23) * *$ & $(-9,9) *$ & $(3,26) *$ \\
\hline \multirow{2}{*}{$\alpha_{0}$} & $-0,189$ & $-0,230$ & $-0,447$ & $-0,590$ & $-0,199$ & $-0,104$ & $-1,889$ & $-0,617$ \\
\hline & $(-12,493)^{*}$ & $(-13,384) *$ & $(-13,437)^{*}$ & $(-11,52)^{*}$ & $(-10,63)^{*}$ & $(-8,64)^{*}$ & $(-8,4) *$ & $(-9,58) *$ \\
\hline \multirow[t]{2}{*}{$\lambda_{1}$} & 0,151 & 0,227 & 0,251 & 0,247 & 0,186 & $-0,036$ & 0,310 & 0,195 \\
\hline & $(19,170)^{*}$ & $(19,766) *$ & $(22,107)^{*}$ & $(19,55)^{*}$ & $(15,38)^{*}$ & $(-2,30) * *$ & $(7,5) *$ & $(11,0)^{*}$ \\
\hline \multirow{2}{*}{$\alpha_{1}$} & $-0,018$ & $-0,029$ & $-0,021$ & $-0,046$ & $-0,009$ & 0,128 & 0,188 & $-0,052$ \\
\hline & $(-3,745)^{*}$ & $(-3,906) *$ & $(-2,919)^{*}$ & $(-4,73)^{*}$ & $(-0,87) \mathrm{ns}$ & $(8,62)^{*}$ & $(5,6) *$ & $(-5,18) *$ \\
\hline \multirow{2}{*}{$\beta_{1}$} & 0,989 & 0,989 & 0,956 & 0,943 & 0,987 & 0,983 & 0,677 & 0,936 \\
\hline & $(582,968)^{*}$ & $(438,152)^{*}$ & $(210,564)^{*}$ & $(146,45)^{*}$ & $(325,37)^{*}$ & $(411,9)^{*}$ & $(17,1)^{*}$ & $(123,7) *$ \\
\hline \multirow{2}{*}{$\chi_{1}$} & 2,96E-09 & $-3,44 E-08$ & $1,06 \mathrm{E}-07$ & $1,75 \mathrm{E}-09$ & $-1,63 \mathrm{E}-07$ & $1,18 E-09$ & $4 E-06$ & $6 E-09$ \\
\hline & $(1,029) \mathrm{ns}$ & $(-1,93) * * *$ & $(5,601)^{*}$ & $(0,63) \mathrm{ns}$ & $(-1,9) * * *$ & $(1,22) n s$ & $(8,1)^{*}$ & $(4,788) *$ \\
\hline L-Box (24) & 32,074 & 36,823 & 35,270 & 20,380 & 22,306 & 15,206 & 41,952 & 44,450 \\
\hline $\begin{array}{l}\text { For the } \\
\text { mean }\end{array}$ & {$[0,099]$} & {$[0,034]$} & {$[0,049]$} & {$[0,619]$} & {$[0,502]$} & {$[0,887]$} & {$[0,01]$} & {$[0,005]$} \\
\hline L-Box (24) & 44,042 & 20,314 & 30,953 & 21,043 & 30,805 & 22,703 & 71,73 & 16,598 \\
\hline $\begin{array}{l}\text { For the } \\
\text { variance }\end{array}$ & {$[0,005]$} & {$[0,623]$} & {$[0,124]$} & {$[0,578]$} & {$[0,128]$} & {$[0,478]$} & {$[0,00]$} & {$[0,828]$} \\
\hline ML & 7278,117 & 3898,098 & 3453,414 & 6550,46 & 2732,53 & 614,26 & 1095,9 & 7172,9 \\
\hline LM Test & $20,305^{*}$ & $0,063 n s$ & $3,631 * * *$ & $7,301 *$ & $19,68^{*}$ & $0,098 n s$ & $0,07 n s$ & $1,717 n s$ \\
\hline$\alpha_{1}+\beta_{1}$ & 0,971 & 0,96 & 0,935 & 0,897 & 0,978 & 1,111 & 0,865 & 0,884 \\
\hline
\end{tabular}

$\mathrm{ns}=$ non-significant; $\mathrm{ML}=$ Maximum Likelihood; $* 1 \%$ significance; $* * 5 \%$ significance; $* * * 10 \%$ significance; ( ) $\mathrm{z}$ statistic; [ ] p-value. Note: The information in italic were excluded from the analysis as a result of the non-rejection of the null hypothesis in the LM test. Source: Estimation results. 
Table 2-c - Estimation results of the EGARCH model with lagged trading volume

\begin{tabular}{|c|c|c|c|c|c|c|c|c|c|}
\hline Company & Santista & Souza Cruz & Suzano & Teka & Vicunha & Vigor & Votorantim & Weg & Yara Brasil \\
\hline \multirow[t]{2}{*}{$a$} & 0,002 & 0,0009 & 0,001 & $-0,002$ & 0,0006 & 0,003 & 0,0003 & 0,002 & $-0,001$ \\
\hline & $(3,755) *$ & $(2,591) *$ & $(2,9)^{*}$ & $(-2,3)^{* *}$ & $(0,81) n s$ & $(2,4)^{* * *}$ & $(0,561) \mathrm{ns}$ & $(4,8)^{*}$ & $(-1,205) \mathrm{ns}$ \\
\hline \multirow[t]{2}{*}{$b$} & $-0,046$ & $-0,017$ & 0,0004 & $-0,157$ & $-0,315$ & 0,051 & 0,0354 & $-0,072$ & $-0,139$ \\
\hline & $(-7,414)^{*}$ & $(-0,96) n s$ & $(0,02) \mathrm{ns}$ & $(-7,8) *$ & $(-5,97) *$ & $(2,1)^{* * *}$ & $(1,72)^{* * *}$ & $(-3,93)^{*}$ & $(-7,484) *$ \\
\hline \multirow{2}{*}{$\alpha_{0}$} & $-10,425$ & $-0,689$ & $-0,238$ & $-0,279$ & $-0,879$ & $-0,107$ & $-2,193$ & $-0,103$ & $-0,072$ \\
\hline & $(-358,9)^{*}$ & $(-10,75)^{*}$ & $(-10,4)^{*}$ & $(-9,1)^{*}$ & $(-15,3)^{*}$ & $(-11)^{*}$ & $(-14,53) *$ & $(-9,1)^{*}$ & $(-12,319) *$ \\
\hline \multirow{2}{*}{$\lambda_{1}$} & 0,405 & 0,244 & 0,152 & 0,185 & 0,649 & 0,132 & 0,3842 & 0,101 & 0,099 \\
\hline & $(77,0)^{*}$ & $(15,75) *$ & $(14,1)^{*}$ & $(14,8)^{*}$ & $(17,8)^{*}$ & $(15,3)^{*}$ & $(18,97)^{*}$ & $(17,3)^{*}$ & $(17,159) *$ \\
\hline \multirow{2}{*}{$\alpha_{1}$} & 0,214 & $-0,021$ & $-0,004$ & $-0,015$ & $-0,114$ & $-0,001$ & $-0,029$ & $-0,019$ & $-0,023$ \\
\hline & $(64,8)^{*}$ & $(-2,3) * *$ & $(-0,6) \mathrm{ns}$ & $(-1,8)^{* * *}$ & $(-4,3) *$ & $(-0,2) \mathrm{ns}$ & $(-2,04) * *$ & $(-3,57)^{*}$ & $(-5,214)^{*}$ \\
\hline \multirow{2}{*}{$\beta_{1}$} & $-0,655$ & 0,932 & 0,982 & 0,976 & 0,916 & 0,996 & 0,737 & 0,995 & 0,999 \\
\hline & $(-135,7)^{*}$ & $(119,5)^{*}$ & $(375,1)^{*}$ & $(209,1)^{*}$ & $(88,1)^{*}$ & $(655)^{*}$ & $(36,23)^{*}$ & $(735,7)^{*}$ & $(1440,1)^{*}$ \\
\hline \multirow{2}{*}{$\chi_{1}$} & $3,1 \mathrm{E}-07$ & $1,06 E-08$ & $1,42 \mathrm{E}-09$ & $-3,5 \mathrm{E}-08$ & $-1 E-06$ & $1 \mathrm{E}-07$ & $2,30 \mathrm{E}-08$ & $-7 \mathrm{E}-10$ & $-2,02 \mathrm{E}-08$ \\
\hline & $(6,45)^{*}$ & $(4,385) *$ & $(1,38) \mathrm{ns}$ & $(-0,6) \mathrm{ns}$ & $(-4,5) *$ & $(8,8)^{*}$ & $(6,84)^{*}$ & $(-0,4) \mathrm{ns}$ & $(-1,363) \mathrm{ns}$ \\
\hline L-Box (24) & 205,95 & 27,430 & 24,046 & 14,839 & 26,316 & 51,743 & 34,522 & 29,595 & 28,542 \\
\hline For the mean & {$[0,000]$} & {$[0,238]$} & {$[0,401]$} & {$[0,900]$} & {$[0,286]$} & {$[0,001]$} & {$[0,058]$} & {$[0,161]$} & {$[0,196]$} \\
\hline L-Box (24) & 143,59 & 33,309 & 41,250 & 50,627 & 26,077 & 30,392 & 79,110 & 57,762 & 23,130 \\
\hline For the variance & {$[0,000]$} & {$[0,076]$} & {$[0,011]$} & {$[0,001]$} & {$[0,297]$} & {$[0,138]$} & {$[0,000\}$} & {$[0,000]$} & {$[0,453]$} \\
\hline ML & 2786,3 & 7172,1 & 6105,1 & 3756,2 & 717,6 & 1753,7 & 6675,64 & 5295,2 & 2566,5 \\
\hline LM Test & $3,5 * * *$ & $1,703 n s$ & $10,031^{*}$ & $34,96^{*}$ & $0,14 n s$ & $6,13 * *$ & $4,208 * *$ & $5,413^{* *}$ & $9,253 * *$ \\
\hline$\alpha_{1}+\beta_{1}$ & $-0,441$ & 0,911 & 0,978 & 0,961 & 0,802 & 0,995 & 0,708 & 0,936 & 0,976 \\
\hline
\end{tabular}

Another important result is that the estimated trading volume coefficient $\chi_{1}$ was significant for the majority of the estimated models, is a variable that should be taken into account in an investment and risk management environment. Also, it is important to notice that volume did not reduce the importance of $\alpha$ and $\beta$ in the representation of the volatility dynamics for Brazilian agribusiness companies, as expected. Indeed, this result raises some interesting research questions: does it indicate that volatility is better explained by its past behavior than by volume? The significance observed for the $\chi_{1}$ coefficient can be an indication that volume is an endogenous variable? Is volume an suitable proxy for information innovation?

In order to answer these questions, some important research issues related to the results of this study are: the investigation of a dynamic relationship between volatility and volume using some alternative approaches, such as Markovswitching models, non-linear Granger Causality tests and Vector Autoregressions that consider liquidity as a relevant variable in the relation between returns and trading volume. Also, alternative estimation techniques based on the use of instrumental variables, in order to capture in an efficient manner 
THE ACCOUNTANCY OF THE POTENTIAL INCOME LOST DUE PREMATURE DEATH: DIFFERENCES DETERMINED BY GENDER
Valéria Gama Fully Bressan

Aureliano Angel Bressam

João Eustáquio de Lima

Marcelo José Braga the arrival of new information to the market using alternative liquidity measures as instruments, can be useful.

Finally, the hypothesis that trading volume is a good proxy for information innovations was not verified for the analyzed sample, since the EGARCH effects were still statistically significant. Although these results can be due to the existence of short-term market inefficiencies or noise trading, they are restricted to the sample and the period considered in this study.

\section{REFERENCES}

ALEXANDER, C. Market Models: A guide to financial data analysis. England: Wiley, 2001. 494p.

ANDERSEN, T.G. Return volatility and trading volume: An information flow interpretation of stochastic volatility. Journal of Finance, ano LI, n. 1, march 1996. p. 169-204.

BESSEMBINDER, H.; SEGUIN, P.J. Price volatility, trading volume, and market depth: Evidence from futures markets. Journal of Financial and Quantitative Analysis. Vol. 28, n. 1, March, 1993, p. 21-39.

BLACK, F. Noise. Journal of Finance, vol. XLI, n.3, p. 529-543, 1986.

BLUME, L.; EASLEY, D.; O'HARA, M. Market statistics and technical analysis: The role of volume. Journal of Finance, vol XLIX, n. 1, March, 1994. p. 153-182.

BROOKS, C. Introdutory econometrics for finance. Cambridge: Cambridge University Press, 2002. 701p.

CHORDIA, T.; SWAMINATHAN, B. Trading volume and cross-autocorrelations in stock returns. Journal of Finance, vol LV, n. 3, April, 2000. p. 913-935.

CHEN, G.; FIRTH, M.; RUI, O.M. The dynamic relation between stock returns, trading volume, and volatility. The Financial Review, Vol. 38, 2001, p. 153-174.

CLARK, P.K. A subordinated stochastic process model with finite variance for speculative prices. Econometrica, Vol. 41, Issue 1, January, 1973, p135-155.

CROUCH, R.L. The volume of transactions and price changes on the New York Stock Exchange. Financial Analysis Journal. Jul-ago, 1970. p. 104- 109.

ENDERS, W. Applied Econometric Time Series. 2 ed. USA: Wiley, 2004. 460p.

EPPS, T.W; EPPS, M.L.. The stochastic dependence of security price changes and transaction volumes: Implications for the mixture-of-distributions hypothesis.

Econometrica, vol. 44, Issue 2, March, 1976. p. 305-321.

GALLANT, A.R.; ROSSI, P.E.; TAUCHEN, G. Stock prices and volume. Review of Financial Studies, Vol. 5, Issue 2, 1992, p. 199-242

GRANGER, C.W.J.; MORGENSTERN, O. Spectral Analysis of New York Stock Market Prices. Kyklos, XVI, 1963. Citado por: CROUCH, Robert L. The volume of transactions 
and price changes on the New York Stock Exchange. Financial Analysis Journal. Julago, 1970. p. 104- 109.

HARRIS, L. Cross-security tests of the mixture of distribution hypothesis. Journal of Financial and Quantitative Analysis, Vol.21, n. 1, March, 1986, p. 39-46.

HIEMSTRA, C.; JONES, J.D. Testing for Linear and Nonlinear Granger Causality in the Stock Price-Volume Relation. Journal of Finance, vol XLIX, n. 5, December, 1994. p. 1639- 1664.

KARPOFF, J.M. The relation between price changes and trading volume: A survey. Journal of Financial and Quantitative Analysis. Vol 22, n. 1, March, 1987. p.109-126.

KUO, W.; HSU, H.; CHIANG, C. Trading volume and cross-autocorrelations of stock returns in emerging markets: Evidence from the taiwan stock market. Review of Pacific Basin Financial Markets and Policies, Vol. 7, No. 4 ,2004, p. 509-524.

MORETIN, P.A.; TOLOI, C.M.C. Análise de séries temporais. São Paulo: Egard Blücher, 2004. 535p.

NAJAND, M.; YUNG, K. A GARCH Examination of the Relationship between Volume and Price Variability in Futures Markets. Journal of Futures Markets, October 1991, Vol. 11 Issue 5, p.613-621.

NELSON, D. B. Conditional heteroskedasticity in asset returns: A new approach.

Econometrica, 59, 1991, p. 323-370. Citado por: HIEMSTRA, Craig; JONES, Jonathan D. Testing for Linear and Nonlinear Granger Causality in the Stock Price-Volume Relation. Journal of Finance, vol XLIX, n. 5, December, 1994. p. 1639- 1664.

ROGALSKI, Richard J. The dependence of prices and volume. Review of Economics and Statistics. Vol. 60 Issue 2, May, 1978. p. 268- 274.

SILVAPULLE, P.; CHOI, J. Testing for linear and nonlinear Granger causality in the stock price-volume relation: Korean Evidence. The Quartely Review of Economics and Finance, Vol. 39, No. 1, 1999, p. 59-76.

TABAK, B.M.; GUERRA, S.M. The dynamics of the price-volume relationship: linear and nonlinear Granger causality applied to the Brazilian stock market. In: ENCONTRO BRASILEIRO DE FINANÇAS, 3, 2003, São Paulo, Anais ... São Paulo: SBFIN, 2003.

TAUCHEN, G. E.; PITTS, M. The price variability-volume relationship on speculative markets. Econometrica, vol. 51, Issue 2, March, 1983. p. 485-505.

TAYLOR, S.J. Asset Price Dynamics, Volatility and Prediction. Princeton, Princeton University Press, 2005.

WATANABE, T. Price volatility, trading volume, and market depth: Evidence from the Japanese stock index futures market. Applied Financial Economics, 11, 2001, p.651-658.

WESTERFIELD, R. The distribution of common stock price changes: An application of transacions time and subordinated stochastic models. Journal of Financial and

Quantitative Analysis, Vol.12, Issue 5, December, 1977, p. 743-765.

$$
====\mathrm{RC} \& \mathrm{C}====
$$

